
www.globaljournalseries.com; Info@globaljournalseries.com

\title{
SOURCES OF INFORMATION ON AWARENESS AND STRATEGIC MANAGEMENT OF GREEN MARKETING IN SOUTHERN SENATORIAL ZONE OF CROSS RIVER STATE, NIGERIA
}

\section{CHARLES EFFIONG, EFFIOM EFFIOM INAMETI, GRACE JAMIE PEPPLE AND NAOMI A. ERNEST}

(Received 23 May 2018; Revision Accepted 4 July 2018)

\begin{abstract}
The study examines the sources of information on awareness and strategic management of green marketing in southern senatorial zone of Cross River State. The descriptive research design was adopted for the study. The stratified random and judgmental sampling design were used in the selection of 210 elements. The statistical data estimation was carried out using the Pearson Product Moment Correlation analysis technique. The study established that there are significant relationships between television and radio sources of information toward awareness and strategic management of green marketing. The study recommended that television and radio media should be used to strongly encourage reportages, documentary film shows and footages, educational programs and discussion environmental issues in public and private own television and radio stations to enable the general public understand, appreciate and know much about the environment.
\end{abstract}

KEYWORDS: Strategic Management, Information, Sources of Information, Marketing, Green marketing, Cross River State.

\section{INTRODUCTION}

Business forms the live wire of any economy. It encompasses and permeate all economic activities, particularly those aimed at earning profit, by anticipating and satisfying the needs and wants of the people in the society (Effiong, Usoro \& Ekpenyong, 2017). Business does not exist in a vacuum but within an environment. It interacts with the environment in an "input and output" symbiotic relationship in carrying out its economic operations. Notably, most business activities have affected the balance of nature and the ecosystems. This of course have created environmental challenges, hazards and pollutions that has an effect on life sustainability, development and growth. Thus the protection and management of the environment is imperatively crucial to business development, survival, growth and expansion. This is a truism as business economic activities impact on the environment. Acknowledgement of this environmental challenges and degradations, which threatens life and business existence and quiddities gave an impetus and awakening to a new horizon in which contemporary green business marketing orientation evolved.

The study adopts an excerpt of Onoja (2014) research study: "Environmental awareness and attitude of senior secondary

Charles Effiong, Department of Business Management, University of Calabar, Cross River State, Nigeria. Effiom Effiom inameti, Department of Marketing, University of Calabar, Cross River State, Nigeria. Grace Jamie Pepple, Department of Business Management, University of Calabar, Cross River State, Nigeria. Naomi A. Ernest, Department of Marketing, University of Calabar, Cross River State, Nigeria.

(C) 2018 Bachudo Science Co. Ltd. This work is licensed under Creative Commons Attribution 4.0 International license. 
school students in Education Zone of Kogi State". Onoja (2014:1) posited that:

"Environment is the totality of circumstances surrounding an organism or a group of organisms. Anikweze, (1998) defined environment as the physical and non-physical space in which human beings start their lives, mature, grow, develop and eventually die, and such environment according to his view could be physical, mental, emotional or social. These views about the environment implied that every single factor whether biotic or abiotic that affect the life of an individual, constitutes the individuals' environment. Thus, environment is a very important factor in the growth and development of an individual, as its' influence can build or mar the individuals. Eboh, (2009) posited that environment refers to a person's surroundings and the objects therein.

The impact of human activities on the environment is on the increase. Luck, Daily and Ehrlich (2003) noted that the interconnected symptoms of assault on the environment and their consequences includes climate change, caused by emission of greenhouse gases which is a major environmental problem and land degradation. Luck et. al. (2003) further explained that stratospheric ozone depletion has a number of harmful effects on the environment which causes widespread injury to human, forest and crops. Land degradation, according to him, this leads to decline in productive capacity of land or its ability to produce environmental services such as recycling nutrients as result of population pressure, rampart deforestation, crude oil spillage, gas flaring, overgrazing and misuse of agrochemicals and others.

The World Health Organization traced emergent diseases and leading causes of death globally to environmental change (WHO, 2010). The report further indicates that a number of factors currently contribute to the appearance and spread of contagious diseases. Patton (2002), noted that humans are causing the environmental change on a massive scale, cutting forests, impounding rivers, creating unhealthy urban surroundings and habitat change and elimination of predators favour disease carrying organisms, such as mice, rats, mosquitoes among others. In the same vein, Cunningham and Cunningham (2002) observed that nearly three quarters of the world major fish stocks are over fished or are being harvested beyond a sustainable rate, and soil degradation has affected two-thirds of the world agricultural land in the last 50 years.

Awareness and consciousness are in some respect synonymous. The Longman Dictionary of contemporary English (2009) defines awareness as the knowledge or understanding of a particular subject or situation, the ability to notice something using sense and also refers to someone's idea, feelings or opinions about life, while consciousness is also defined by the above source as the condition of being awake and able to understand what is happening around you, the state of knowing that something exists or is true, and also implies someone's ideas, feelings or opinions about life politics, environment and so on.

Chinedu (2008) viewed awareness as the conditions of being aware and able to understand what is happening around one. In agreement with the above views, Wikipedia (2009) equates awareness with perception of, conscious of, acquaintance with, enlightenment with, mindfulness of, cognizance of something. In the context of this study and in 
agreement with the above views, awareness implies understanding and knowledge of the activities and events (such as desertification, land degradation, climate change, deforestation, atmospheric and land pollution, flooding and so on) going on around one's environment."

Any product which is ecofriendly and having little damage to environment may be considered as "green" product. All businesses have the responsibility to reduce the environmental pollution in their production process. A product which is made of raw material must be designed or manufactured in such a way that it must not destroy natural resources. It is being at various times discussed in contemporary researches that waste management is of high importance in this regard. Every business needs to develop an ecofriendly design and packaging which have the capability of minimizing pollution and hazards (Arseculeratne \& Yazdanifard, 2014). It is therefore imperative that this environmental challenges, require strategic management approach and brain storming to articulate strategies that would achieve the desire objective and goal accomplishment.

Hitt, Ireland, and Hoskisson, (2017) buttressed that strategic management process is intended to be a rational approach to help respond to the challenges of the $21^{\text {st }}$ century environmental issues effectively. The process requires studying of the environment to identify environmental issues, threats to life and survival and determine core competencies in the pursuit of desired strategic outcome. Effiong, Inameti, Ernest and Arikpo (2018) postulated that with the environmental knowledge, the formulation of a strategy intent to leverage resources, capabilities, and core competencies is undertaking to win the environmental challenges and "battles". It is against this backdrop that this study examines the sources of information on awareness and Strategic management of green marketing in Southern Senatorial Zone of Cross River State.

\subsection{STATEMENT OF THE PROBLEM}

The media used in the investigation and reportage of environmental issues and awareness are mostly newspaper, radio and television programs which are widely and frequently used modern media. There are set of ideas about media tasks in the society, like providing educational information about events and conditions in the society and the world in general, facilitating innovation, adaptation and progress. Awareness creation activities carried out by the different sources of information and the various anti-environmental degradation clubs and organizations that deal with environmental protection have not yielded much effectiveness and so have been unsuccessful. It is noted that both urban and rural people were not well informed about the mode of destruction and need for protection of the environment. One of the causes of the deep rooted environmental problems in Nigeria is lack of awareness inclusive of high citizenry illiteracy level which is at the very heart of the inappropriate strategic management and utilization of environmental resources.

The focal view of the study is that; it appears that the magnitude or degree of environmental problems like soil erosion, land degradation, deforestation, bush burning, flooding among others is higher and more destructive in southern senatorial zone of Cross River. Sequel, the study becomes crucial, imperative and justified considering the present environmental trends, as such contemporary study have not been done in Southern Senatorial Zone of Cross River State. The study intends to fill this gap. Thus, the problem of the study put in question form is, what are the sources of information towards awareness and strategic management of green marketing in Southern Senatorial Zone of Cross River State?

\subsection{Objectives of the Study}

The general objective of the study is to ascertain the sources of information towards awareness and strategic management of green marketing in southern senatorial zone of Cross River State. Specifically, the study intends to:

1) examine the relationship between television information towards awareness and strategic management of green marketing in Southern Senatorial Zone of cross River State;

2) determine the relationship between radio information towards awareness and strategic management of green marketing in Southern Senatorial Zone of cross River State.

\section{$1.4 \quad$ Research Questions} this study:

\section{The following research questions guided}


1) Is there any relationship between television information towards awareness and strategic management of green marketing in Southern Senatorial Zone of Cross River State?

2) What is the relationship between radio information toward awareness and strategic management of green marketing in Southern Senatorial Zone of Cross River State?

\subsection{Research hypotheses}

The following hypotheses were formulated to guide this study:

1) There is no significant relationship between television information towards awareness and strategic management of green marketing in southern senatorial zone of Cross River State.

2) There is no significant relationship between radio information towards awareness and strategic management of green marketing in southern senatorial zone of Cross River State.

\subsection{Significance of the Study}

The findings of this study will be beneficial to the general public, professional/antienvironmental protection NGOs and campaign champions, students, teachers, implementers of green marketing and conservation projects, government and curriculum planners in comprehending the effectiveness of television and radio information on awareness of environmental discuss and campaign.

\subsection{Scope of the Study}

The study was restricted to sources of information on awareness and strategic management of green marketing in southern senatorial zone of cross river state. The zone covers seven (7) local government areas which includes: Akamkpa, Akpabuyo, Bakassi, Biase, Calabar South, Calabar Municipality, and Odukpani. The study dealt with two electronic sources of information which includes television and radio media of information.

\subsection{Limitations of the Study}

The high citizenry illiteracy level posed constrain on the study based on the large population of the study. This was however overcome by personal interview interpreters.

\subsection{REVIEW OF RELATED LITERATURE}

\subsection{Theoretical framework}

This study is anchored on the Strategic Management theory (SMT) and the Media Framing theory(MFT).

\subsubsection{Strategic management theory(SMT)}

Adopting from Effiong, et. al. (2018) "Strategic management theory connotes a supposition, proposition or a system of ideas proposed to explicate "the origin, evolution, principles and applications of strategic management. The strategic management theories mainly stem from the systems perspective, contingency approach and information technology approach to environment management" Effiong, et. al. (2018), posited the strategic management theories as the gainmaximising and competition-based theory; resource-based theory; survival-based theory; human resource-based theory, agency theory and contingency theory. The gain-maximising and competition-based theory is based on the notion that society's mission and main objective is to maximize long term gains through developing sustainable strategies to combat environmental issues seen as competitive rivals. The perspective view of this theory acknowledges the environmental knowledge and awareness as critical factor for attaining and sustaining environmental competitive advantage over environmental challenges(competitive rivals). The resource-based theory stems from the management philosophy that society's competitive advantage lies in the society's resources, capabilities and core competence to handle environmental issues (Effiong, et. al. 2017). Thus, Barney, (1995) postulated that competitive advantage strongly depends on the unique, inimitable resources and capabilities the business or society possesses, rather than simply evaluating environmental opportunities and threats in conducting business and societal activities. The survival-based theory centers on the management philosophy that societies need to continuously adapt to its competitive environment in order to survive. The humanbased theory emphasizes the importance of human element in the strategy development process of the business or society. The Agency theory underlies the important relationship between the Stakeholders and citizenry in ensuring the societal or business environmental successes. Lastly, the contingency theory holds 
the management tenet that there is no one best approach or method to manage environmental issues but the management strategy should be based on the situation and condition being experienced.

A point to reiterate is that strategic management connotes prudent management of resources to achieve goals and objectives. It encompasses setting objectives, vision, analyzing the competitive environment, formulating, implementing, and analyzing/evaluating the effectiveness of the strategies implemented. It is the continuous planning, monitoring, analysis and assessment of all that is necessary to meet goals and objectives (Effiong, et. al, 2018).

For the purpose of this study, besides other main strategic management theories as mention above, the gain-maximising and competition-based theory would be the underlying theoretical foundation applied and fundamental basis of the variables. The objective been to examine television and radio information towards awareness and strategic management of green marketing in southern senatorial zone of Cross River State.

\subsubsection{Media Framing Theory (MFT) - (Tuchman, 1999)}

A frame in a communication "organizes everyday reality" (Tuchman, 1999) by providing "meaning to an unfolding strip of events" (Gamson and Modigliani 1987) and promoting "particular definitions and interpretations of issues. To frame is to select some aspects of a perceived reality and make them more salient in a communicating text, in such a way as to promote a particular problem definition, causal interpretation, moral evaluation, and/or treatment recommendation (Scheufele (1999). Framing refers to the process by which people develop a particular conceptualization of an issue or reorient their thinking about an issue (Chong \& Drunkman, 2007). Mass media actively set the frames of reference that readers or viewers use to interpret and discuss public events. According to Neuman(2012) they give the story a spin taking into account their organizational and modality constraints, professional judgments, and certain judgments about the audience. On the other hand, recipients information processing and interpretation are influenced by preexisting meaning structures or schemas. Scheufele (1999) observes that because frames have to be considered schemes for both presenting and comprehending news, two concepts of framing can be specified: media frames and individual frames. This terminological and conceptual distinction follows the Kinder and Sanders (1990) suggestion that frames serve both as "devices embedded in political discourse which is equivalent to the concept of media frames, and as internal structures of the mind, which is equivalent to individual frames. According to Gitlin (1980), frames "largely unspoken and unacknowledged, organize the world both for journalists who report it and, in some important degree for us who rely on the reports.

\subsubsection{An overview of sources of information}

An information source is a person, thing, or place from which information comes, arises, or is obtained. That source might then inform a person about something or provide knowledge about it. Information sources are divided into separate distinct categories, primary, secondary, tertiary, and so on. One may assume, automatically, that academic text books are the primary source of information when the person is engaged in a formal study programme (Habermas, 2014). This may be true, to a degree, usually there is little need to question the credibility of such texts - they have probably been recommended by a tutor. There are, however, many other sources of information which should not be overlooked. Such sources include: the internet, newspapers, journals, transcripts from radio or TV programmes, leaflets, photographs and other artifacts (manmade objects).

Cheng and Moore (2015), asserted that within the category of books there are many different types and genres, for example: fiction and non-fiction, including dictionaries, encyclopedia, biographies, almanacs, archives, yearbooks and atlases, to name just a few. There are even more categories of websites and other internet resources. All sources of information can be of relevance depending on the subject matter of the research or project you're working on. It is important to understand that all information will have a certain degree of validity or otherwise. A document can be easily forged or altered, especially on the internet where anybody can publish anything. It is therefore necessary to use judgment when deciding which documents to use in the context of your study.

According to Sage (2017) all documents that a person uses for study fall into one of three categories: 
Primary Documents: A primary document is a document that was written at the time of an event or period of research. Primary documents therefore include literary texts, letters, speeches and historical documents such as birth certificates and diaries. A live news-feed (or the transcript of) is a primary source - recording events as they unfold. Of course any major news event (like the Olympic Games) is likely to have several primary sources, accounts from different broadcasters. To get a fuller idea of the event you may look at more than one primary source of information - taking into account biases, pointsof-view and personal or cultural perceptions.

Secondary Documents: A secondary document is written after an event - usually the authors will not have witnessed the event themselves. Such documents are usually written with reference to primary documents and attempt to provide an interpretation. Core texts - academic texts related to the topic being studied - are an example of secondary documents. In current affairs a secondary source would be a standard news story. A story that has been reported after the event. As a secondary source is a writer's interpretation of what happened (a primary source) it is more likely to contain observations, bias and subjective commentary that try to explain the event and put it into some sort of context.

Tertiary Documents: Tertiary documents usually act as pointers to primary and secondary documents. They are indexes, directories, bibliographies and other categorized collections of information - documents that you can turn to and be guided to other, potentially relevant, documents on a particular subject. For example, checking the bibliography of books can help to lead you to further research material or to looking at a list of similar stories on a news website. Primarily one needs to be aware of where to look for information, how to access it and how to use it. The researcher must also be able to scrutinize the sources to check that they are relevant and of a suitable nature to be included within the work.

The evaluation of different environmental problems indicated that environmental communication is the basis for environmental awareness creation through a complex interactive and iterative information system. According to Habermas (2014) communication strategy should be designed for populations that are exposed to different environmental problems and who may not hear and understand environmental information.

Stables (1996) defined environmental communication as pragmatic and it constitutes symbolic action in the public sphere mediating beliefs, attitudes and behavior relating to nature and environmental problems. Environmental communications is one of many forms of communication that are engaged in social debate about environmental issues or problems. The dominant structure of the prevalent environmental communication framework hinges not only on the separation between environment and communication, but also between the communicator and the audience.

One of the most pressing and contentious counterpart points in the realm of environmental policy is the potential choice between environmental preservation and economic growth. To be sure, the environmenteconomy trade off plays out in global environmental debate, as first world economic growth is often criticized as driving worldwide resource depletion. This influences the environmental views of community and their overall awareness of how the various assets are affected. It is assumed that people who are more environmentally aware are more likely to participate and tolerate measures that lessen the burden on the environment.

\subsubsection{Television Information and Awareness of green marketing}

The study adopts an excerpt of Nazari, Hasbullah, Parhizkar, Shirazi and Marioriad (2009) research study "The impact of visuals: Using television program to transform environmental health concepts to people" position on this sub-title discuss. According to Nazari et, al. (2009:2619):

"Among the wide diversity of media, radio and television have outstanding position because of the informal teaching purposes they potentially retain (Tankard \& Severin, 2000). It has always been believed that educational television can aid transmission of information and help reinforcement, learning and application of particular skills assisting learning procedure. Television should be able to promote public culture and highlight issues such as, public health, traffic, social relations and 
so on and require producing films on these issues for more appropriate changes in the society (Mohsenian \& Malekzadeh, 1997).

In recent decades, the application of mass media resulted in heightening the level of education and caused more efficiency in educational system. The spread and development of television in three decades after the Second World War paved a new ground of modern communication. It seems that ubiquity of television is due to the convenience and accessibility of it in addressing all people and teaching them through easiest method, as people are more inclined to learn something through the easiest way possible (Buren, 2000).

Currently, media offers a lot of information on health issues. In 1990, at least one fourth of the American daily newspapers contained health-related articles. In local American television news, stories on health were among the most common topics. In 1998, American television showed 17 commercials at every hour containing health information. Thus, what is the role of this large amount of health-related information on people and lives. Several researchers have studied the effects of media on public knowledge and behavior (ByrdBredbenne \& Grasso, 2000).

Media are appropriate sources of information for enhancing knowledge on health or medical issues. Relationships have been found between medical information in a television drama and people's knowledge about the topic, as well as between an educational television programme and the level of nutritional knowledge (Alcalay \& Bell, 1996). Television commercials, an information series broadcast as part of the evening news and an information booklet were used to try to make American women with little information thinking about quitting smoking (Freels, Warnecke, Parsons, Johnson, Flay, \& Morera, 1999). Both awareness of and use of folic acid had increased in the Netherlands after a mass media campaign for the periconceptional use of folic acid that started in 1995. It has been found, furthermore, that a soap opera on television was effective in persuading people to take bonemarrow tests, in order to find suitable bone-marrow donors for people suffering from leukaemia (Walle., Cornel, \& Jong-van, 2002).

The influence of media information on the changes of health behaviour is not always strong. In one study, the information was mediated through both print and electronic media, all in the Vietnamese language; however, the intervention only managed to promote general check-ups and Pap tests. In other words, the intervention did not have positive effects on promoting currency for any of the tests. The researchers drew the conclusion that a mediabased intervention alone could only perhaps lead to better consciousness, but not to behavioural changes in any greater extent (Jenkins, McPhee, Bird, Pham, \& Nguyen, 1999).

$\begin{aligned} & \text { According to the } \\ & \text { adduced by Wofinition } \\ & \text { Organization }\end{aligned}$
(WHO), environmental health refers to the control of all elements of our life environment that are/will be influential in one's mental, physical and social health (Lopez-Sosa \& Tévar, 2005). The significance of protecting the environment is quite evident at the present time. Implementation and application of any program undoubtedly requires sufficient knowledge on the 
environment and anything that pollutes and contaminates it. Contamination of the environment is considered an alarming threat for all living beings on the earth. Therefore, all of us, as conscientious human beings, should assume responsibility and be completely aware in this regard (Dasgupta, 2005).

The quality of the air changes everyday and even every hour. Environment Protection Agency (EPA) of the United States and other contiguous agencies attempt to report information related to the air quality so that it can be understandable to the public. What the civilized man of today demands more, is the clean and fresh air. Besides the physical and mental perils, one of the most disturbing perspectives of air pollution is economic losses (Vandenberg, 2005).Nowadays, due to the multiplicity and wide spread of microbes and diseases, there is great concern and attention to the removal of waste materials. Disinfection using microwaves, sterilization by steam and chemical disinfection are modern techniques developed in recent years for preliminary refinement of waste materials that have been replaced instead of burial or burning of the garbage (Saker, 2004).

In many developing countries, there is not adequate service for removal of waste materials and refining the sewage. Furthermore, many industrial factories do not abide by the environmental rules. As a result, the residents of such societies have low level of health and suffer from environmental issues. In such communities, in order to keep balance between the environment and the population growth and between economic development and the growth of urbanization, there needs to have enormous capital investment. It is about few decades that man's dwelling place has been threatened by the world's industrialization and accumulation of waste materials that will result in threatening public health if decreasing the pollution is not taken into serious consideration (Groom, 2008; Asgharnia, 2002).

According to the statistics presented by World Health Organization (WHO) in 2010, 25000 million people die everyday because of consuming contaminated water. Statistics indicate that one fourth of the beds in hospitals belong to the patients suffering from drinking polluted water. Health of water, therefore, is one of significant issues in human society and that provision of healthy drinking water is based on multi-facet cooperation, awareness and education of people in the consumption and maintaining water resources. Education of hygiene is one of fundamental principles in providing better Preliminary Hygienic Services (PHs). Obtaining information about people's level of awareness on health and hygienic issues is quite indispensable for planning and providing hygienic services (Asgharnia, 2002). The present age is a combination of information and communication; an age in which man needs to have more information and better communication (Asnafi \& Hamidi, 2008). Comprehending the importance of environmental pollution will elicit and provoke people to do something for the reduction of it. To attain such a purpose, mass media should assume responsibility and convey necessary information to people. In this regard, the researchers were intended to determine the effect of television in teaching the concept of environmental health to the people of Yasouj. The main 
emphasis of environmental health lies on issues including water, soil and air. This research also scrutinizes issues as health of water, air and removal of waste materials accordingly".

Media is a powerful tool that can be used to foster development. If effectively utilised, media can play a huge role in raising ecosystem awareness on environmental issues. The public enlightenment of many environmental issues affecting productivity and causing loss of lives can be brought to people's notice through media. Armed with the right information, people can take preventative measures to shield themselves from harm and also take better care of their environment. Television in particular, have wide coverage that can help reach out to the masses through demonstrations on how to prevent environmental problems and cautionary measures to take incase disaster strikes. The media play a critical role in building and sustaining democracies, societies and economies around the world by providing citizens with information necessary to make informed political and economic choices (Coronel, 2018).Through media, issues that hinder development such as environmental degradation can be highlighted and appropriate measures taken to stop their escalation. According to Shanahan (2011) the media can inform vulnerable communities of impacts and how they can adapt them, and can promote mitigation activities that limit the amount of warming the earth experiences. The fight against climate change could be won or lost on the pages of newspapers, in TV and radio broadcasts and on the internet and mobile phones. This is because people need good information to make effective decisions-at the household or global level-and most people get their information about climate change from the media (Shanahan, 2011). Tengbers (2015) states that there are over 2600 global media channels supported by about 3000 satellites that disseminate information to 1.5 billion people all over the world. The media therefore can be relied on as a powerful tool for creating awareness on environmental issues. They can serve as "environmental watchdog", providing vital information and education in their investigative and exploratory reportage.

Burgess (1990) buttressed that the media has a critical role to play in helping to halt and reverse future expansion of environmental problems and to maintain existing efforts in the community. Morgan (2017) is of the opinion that a significant amount of the public's knowledge of environmental issues is likely to come from the media. He further states that much of what people hear about issues such as greenhouse effect, global climate change, ozone depletion, water and air pollution come from the media (or from others who have heard it from the media) since our first-hand knowledge of the state of the environment is likely to be minimal. However, Deacon (2009) noted that this immense role of the media has not been fully realized as political or other development agenda is usually a priority and environmental protection is rarely "high" in the news agenda. The result is most people are not aware of environmental challenges facing humanity and their consequences. The significance of these issues are not prioritize or reflected in media reporting (McQuail, 2017).

Studies done on television programming in Africa reveal that the bulk of airtime is taken up by foreign programmes (Matiro, 2009). A case study of 6 African countries: Ivory Coast, Nigeria, Senegal, Uganda, Zimbabwe and Kenya (Maly \& Varis, 2015) showed that programming was characterized by high dependence on imported programs, a marked absence of indigenous programs and an entertainment category which occupied 48 percent of total broadcast time.

\subsubsection{Radio Information towards Awareness of green marketing}

Mass media has been defined as a "means of communication designed to reach and influence large numbers of people" (Encyclopedia Brittanica, 2017). Mass communication is a technology which helps a message to be transmitted among a large number of people at the same time. Thus, it includes newspapers, magazines, television, radio, cinema and the internet (Ball-Rokeach \& DeFleur, 2017).

According to Lee (2009) mass communication history is fairly short. "Mass communication primarily developed in just the last 500 years. Earlier developments, along with technological advances and social change, helped spark the demand and innovation necessary for creating today's mass media " (Lee 2009) . The impact of media on society was probably best summarized by Nobel Prize winner and Harvard University Professor Amartya Sen, who famously said that "no substantial famine has ever occurred in any independent and democratic country with a relatively free press". 
Sullivan (2007) states that media hold tremendous potential to transform lives by improving the quality of education, informing the public about health threats and safe practices to avoid them, serving local communities by bringing attention to their needs and in times of disaster, providing information and sources of assistance to people displaced from their homes. It therefore follows that media can be used as an effective tool for raising awareness on environmental issues.

Morgan (1997) postulated that a significant amount of the public's knowledge of environmental issues is likely to come from the media. Morgan (1997) further postulates that much of what people hear about issues such as greenhouse effect, global climate change, ozone depletion, water and air pollution, and other environmental threats is likely to come from the media (or from others who have heard it from the media) since our first-hand knowledge of the state of the environment is likely to be minimal. Kapur (2011) corroborates the view above and posit that media information tools like radio, television, internet and newspapers, can spread awareness on climate change and environment protection among people faster than personal contact. Shanahan (2011) also buttressed that the media can inform vulnerable communities of potential impacts and how they can adapt to them, and can promote mitigation activities that limit the amount of warming the earth experiences. McCombs (2014) adds that the media could take up a crucial role by providing technical information about relevant environmental problems and possibilities.

\subsection{RESEARCH METHODOLOGY}

\subsection{Research design}

Descriptive research design was adopted in this study. This design was preferred over the others because it is used to find the meaning and obtain an understanding of the present conditions as well as determining the frequency with which something occurs or the relationship between two variables. The results obtained from the design can be analyzed statistically.

\subsection{Study area}

The study area of research was Southern senatorial zone of Cross River State which comprises Akamkpa, Akpabuyo, Bakassi, Biase, Calabar South, Calabar Municipality, and Odukpani. Calabar Metropolis which comprises
Calabar South and Calabar Municipality local government areas of Cross River State. It is the capital of the state, and in the southern senatorial district. It is bounded by the North by Akamkpa, East by Odukpani, West by Akpabuyo and South by Atlantic Ocean. It is located at latitude and longitude at $457 \mathrm{~N}$ and $819 \mathrm{E}$ respectively. It has an area of $406 \mathrm{~km}$ and a population of 562 at 2006 population census (National Population Census, 2006). Calabar Metropolis has a number of retail outlets at different sizes and capacities.

\subsection{Population of the study}

The population of this study consists all buyers or consumers of marketing products in southern senatorial of Cross River State. Therefore, the total population was unknown.

\subsection{Sample size determination}

The researcher adopted Topman formular to determine the sample size of this study from unknown population of buyers. First and foremost, pilot survey was carried out in different areas from the ones used in the main survey with 30 respondents. The results were analyzed using Cronbach's Alpha coefficient to determine the values of positive and negative values of 80 and 20 respectively. Therefore, the sample size for this study was 210 respondents.

\section{Topman formula}

$n \quad=\frac{Z^{2} \bar{P}(1-\bar{P})}{e^{2}}$

$$
\begin{array}{ll}
\text { where } & \\
n^{`}= & \text { Sample size. } \\
Z^{\prime}= & Z-\text { Score } 1.96 \\
P= & \text { Positive responses } 0.8 \\
1-\mathrm{P}= & \text { negative responses } 0.2 \\
\mathrm{e}=\quad \text { tolerable error } 0.5 & \\
\mathrm{n}=\frac{(1.96)^{2} \times 0.8 \times 0.2}{(0.5)^{2}} \\
\mathrm{n}=210
\end{array}
$$

\subsection{Sampling technique}

Stratified random and judgmental sampling designs were used to select the sample elements of 210 respondents in the study. 
3.6 Source of data collection

The main source of data collection was primary source.

\subsection{Instrument for data collection}

The questionnaire was used to collect primary data from respondents

\subsection{Validity and reliability of the instrument \\ Content validity of the instrument was} ensure by face validity test. While the reliability of the instrument was estimated by the Cronbach's Alpha coefficient. The coefficient value were 85 percent and above which made the instrument reliable for this study.

\section{9}

Data treatment technique

The data treatment technique was Pearson's Product Moment Correlation with the aid of SPSS version 21.

\subsection{Data presentation and analysis}

\section{Hypothesis 1:}

There is no significance relationship between television information towards awareness and management of green marketing in Southern Senatorial Zone of Cross River State. The Pearson Product Moment Correlation was adopted to test this hypothesis. The result is as presented

Table1

Table 1: Pearson Product moment correlation coefficient analysis of relationship between television information towards awareness and mgt of green marketing $(\mathrm{N}=210)$.

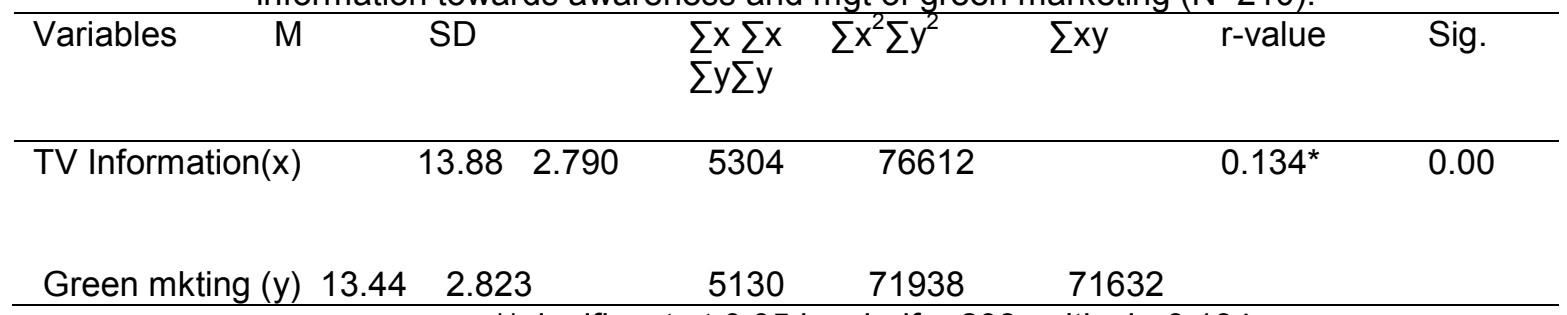

${ }^{* *}$ significant at 0.05 level, $\mathrm{df}=208$, critical r 0.134

The result in Table 1 revealed that the calculated $r$ - value of $0.134^{*}$ is greater than the critical $p$ value of .095 at .05 level of significance with 208 degree of freedom with this result, the null hypothesis which states that, there is no significant relationship between television information towards awareness and management of green marketing in southern senatorial zone of Cross River State was rejected. This implies that television information has a significant relationship with awareness of green marketing in Southern senatorial zone of Cross River State.

\section{Hypothesis 2:}

There is no significance relationship between radio information towards awareness and management of green marketing in southern senatorial zone of Cross River State. The Pearson Product Moment Correlation was adopted to test this hypothesis. The result is as presented

in Table 
Table 2: Pearson Product moment correlation coefficient analysis of the relationship between radio

\begin{tabular}{|c|c|c|c|c|c|c|c|}
\hline Variables & $\mathrm{M}$ & D & $\sum x \sum y$ & $\sum x^{2} \sum y^{2}$ & $\sum x y$ & r.value & Sig \\
\hline Oral inform (x) & 12.43 & 6.14 & 5354 & 87724 & & $0.357^{*}$ & 0.00 \\
\hline Green mktin (y) & 13.13 & 3.31 & 5566 & 73452 & 73572 & & \\
\hline
\end{tabular}

The result in Table 2 revealed that, the calculated r-value of .357 is greater than the critical $p$-value of .95 at .05 level of significance with 208 degrees of freedom. With this result, the null hypothesis was rejected and it was concluded that there is a significant relationship between radio information and awareness of green marketing in Southern Senatorial Zone of Cross River State.

\subsection{DISCUSSION OF FINDINGS}

Television information towards awareness and management of green marketing

The result of this hypothesis showed that television information has a significance relationship with environmental awareness of senior secondary school students in Calabar South. The finding of this hypothesis corroborates Mohsenian and Malekzadeh, (1997) who assert that, it has always been believed that educational television can aid transmission of information and help reinforcement, learning and application of particular skills assisting learning procedure. Television should be able to promote public culture and highlight issues such as, public health, traffic, social relations and so on and require producing films on these issues for more appropriate changes in the society.

Radio information towards awareness and management of green marketing

The result of this hypothesis showed that television information has a significance relationship with environmental awareness of senior secondary school students in Calabar South. The finding of this hypothesis corroborates Morgan (1997) who apt that, a significant amount of the public's knowledge of environmental issues is likely to come from the radio. Morgan (1997) further postulates that much of what people hear about issues such as greenhouse effect, global climate change, ozone depletion, water and air pollution, and other environmental threats is likely to come from the media (or from others who have heard it from the media) since our first-hand knowledge of the state of the environment is likely to be minimal.

\section{CONCLUSION}

Based on the findings of the study, the conclusion drawn from the study was that television information and radio information significantly relate with awareness and management of green marketing in southern senatorial of Cross River State. This means that continuous communication of environmental related issues to the publics would help the people to be aware of the environment and know the basic ways on how to manage our environment properly. The use of television and radio to create awareness about green marketing is very paramount since almost everybody can have access to these two electronic media of communication in rural and urban areas of the state. Therefore the more information dissemination of green marketing through television and radio the more awareness and management oriented of the environment the people will be.

\section{RECOMMENDATIONS}

Based on the findings of the study the following recommendations were made.

1, film shows on environmental issues should be encouraged in public and private television stations to allow the public see and know much about environment.

2, more sponsored radio documentaries or programmes should be encouraged to acquaint the public with the environmental issues and possible ways of management our environment. 


\section{REFERENCES}

Alcalay, R. and Bell, R. A., 1996. Ethnicity and health knowledge gaps: Impact of the California wellness guide on poor African American. Hispanic and non-Hispanic white women. Health Commun, 8(4), 303-329.

Anikweze, C. M., 1998. Threats to adolescent well being. In Orji, S. A. \& Anikweze C. M. (eds) Adolescent Psychology. 109117.

Arseculeratne, D. and Yazdanifard, R., 2014. How green marketing can create a sustainable competitive advantage for a business. International Business Research, $\quad 7(1), \quad$ 130-137. DOI:10.5539/ibr.v7n1p130.

Asgharnia, H. A., 2002. A study on the production of compost using home garbage. http://www.shirazcity.org/Bazyaft/product 9.html.

Asnafi, K. and Hamidi, M., 2008. Media and audiences: New perspective. London: Open University Press.

Ball-Rokeach, S. J. and DeFleur, M, L., 2017. Theories of mass communication (5th Ed). New York: Longmanlnc.

Barney, J. B., 1995. Looking inside for competitive advantage. Academy of Management Executive. 9(4), 49-61. DOI.Org/stable/4165288.

Buren, E. D., 2000. Cultural aspects of communication for development. Tehran: IRIB Press, 110-114.

Burgess, J., 1990. The production and consumption of environmental meanings in the mass media report. Bath: Bath University press.

Byrd-Bredbenner, C. and Grasso, D., 2000. Health, medicine and food messages in television commercials during 1992 and 1998. Journal of School Health, 70(2), 61-65.
Cheng, D. and Moore, S., 2015. Audience analysis. California: Oxford Focal Press.

Chinedu, C., 2008. Environmental education awareness of attitudes of secondary school students in Owerri Education Zone, Imo State. Unpublished M.ED. Thesis of the Department of Science Education, University of Nigeria, Nsukka.

Chong, D. and Drunkman, J. N., 2007. The theory of framingand opinion formation in competitive elite environments. Journal of Communication. 57(1), 99-118. Doi:10.111/j.1460-2466.2006.00331.x

Coronel, S. S., $12^{\text {th }}$ June, 2018. The role of the media in deepening democracy. Retrieved from http://unpan1.un.org/intradoc/groups/publ ic/documents/un/unpan010194.pdf.

Cunningham, W. P. and Cunnngham, M. A., 2002. Principles of environmental sciences: Inquiry and Applications. Beston: McGram Hill Publishers.

Dasgupta, S., V., Deichmann, U., Meisner, C. and Wheeler, D., 2005. Where is the povertyenvironment nexus? Evidence from Cambodia, Lao PDR and Vietnam. World Development, 33(4), 617-638.

Deacon, D., 2009. Researching communication: A practical guide to methods in media cultural Analysis. London: Edward Arnold.

Eboh, E. C., 2009. Introduction: Debating policy options for national development; Enugu forum policy paper 10; African Institute for Applied Economics, Enugu, Nigeria.

Effiong, C., Inameti, E. E., Ernest, A. N. and Arikpo, N. N., 2018. Strategic management of sales promotion techniques on products consumers of selected retail outlets in Calabar metropolis of Cross River State, Nigeria. Global Journal of Social Sciences.17, 2018, 41-53.

Effiong, C., Usoro, A. A. and Ekpenyong, O. E., 2017. The impact of labour turnover on small and medium scale enterprises (SMEs) performance in Cross River State, 
Nigeria. IOSR Journal of Business and Management 19(10), 40-57.

Encyclopedia Brittanica, 2017.

Freels, S. A., Warnecke R. B., Parsons, J. A., Johnson, T. P., Flay, B. R. and Morera, O. F., 1999. Characteristics associated with exposure to and participation in a televised smoking cessation intervention program for women with high school or less education. Preventive Medicine, 28(6), 579-588.

Gamson, and Modigliani., 1987. The changing culture of affirmative action. Research in Political Sociology(3ed.) Greenwich: Jai Press Inc.

Gitlin, Todd, 1980. The whole world is watching: Mass media in the making and unmaking of the new left. Berkeley: University of California Press.

Groom, R., 2008. Ethiopia Country profile. Addis Ababa: Ethiopia. [Online] Retrieved from http://www.News.bbc.co.uk/1/hi/word/Afri ca/countryprofiles/107164.htm2007.PDF [Accessed] 25 June 2009.

Habermas, K., 2014. Masail and ecology, pastoralist's development and wild life Conservation in Tanzania. London: Cambridge University Press.

Hitt, M. A., Ireland, R. D. and Hoskisson R. E., 2017. strategic management: Competitiveness and globalization $\left(12^{\text {th }}\right.$ Ed.) Boston, MA: Cengage Learning

Jenkins, C. N., McPhee, J. A., Bird, J. A., Pham, G. Q. and Nguyen, B. H., 1999. Effect of a media-led education campaign on breast and cervical cancer screening among Vietnamese-American women.

Preventive Medicine, 28: 395-406.

Kinder, D. R. and Sanders, L. M., 1990. Mimicking political debate with survey questions: the case of white opinion on affirmative action for blacks. Social Cognition 8, 73=10.

Kapur, H., 2011. Past and present activities, achievements, and constraints in forest genetic resources conservation. Addis Ababa: University Printing Press.

Lee, I., 2009. Approaches to understand the relationship between texts and audiences. Stockholm: Lud University.

Longman Dictionary of contemporary English., 2009.

Lopez-Sosa, C. and Tevar, R., 2005. The human sexual system in the context of the health sciences. Sex. Disabil., 23, 145-154.

Luck, G., Daily, G. C. and Ehrlich, P. R., 2003. Population diversity and ecosystem services. Trends in Ecology \& Evolution. 18(7), 331-336.

Maly, I. and Varis, P., 2015. The $21^{\text {st }}$-century hipster: On micro-populations in times of super diversity. European Journal of Cultural Studies. 19, 637-653. Doi.org/10.1177/1367549415597920.

Matiro, K., 2009. What is natural? (Online) Retrieved from http//www.worldbank. Org/poverty/. (Accessed) $25^{\text {th }}$ December 2009.

McCombs, L., 2014. Issues in the news and the public agenda: The agenda-setting tradition. New York: Guilford Press.

McQuail, D., 2017. Audience analysis. London: SAGE Publications. URI. http://orca.cf.ac.uk/ id/eprint/56426.

Mohsenian, R. and Malekzadeh, A., 1997. Various Educational Capabilities. New York: Ella-e- Pajouhesh Quarterly, New York.

Morgan, J., 1997. Geo-graphing: Writing the world in geography classrooms. London: Institution of Education.

Morgan, S., 2017. Environmental geography. Allahabad: Bhawan Publication.

Nigeria Bureau of Statistic, National Population Census. 2016.

Nazari, M. R., Hasbullah, A. H., Parhizkar, S. A. R., Shirazi, A. R. and Marioriad, H., 2009. The 
Impact of Visuals: Using Television Program to Transform Environmental Health Concepts to People. Journal of Applied Sciences, 9, 26192624.DOI:10.3923/jas.2009.2619.2624

Neuman, R., 2012. Radio production: A manual for broadcasters (4th Ed.), London: Oxford Focal Press.

Onoja, P. A., 2014. Environmental awareness and attitude of senior secondary school students in Education Zone of Kogi State. Unpublished Master Degree thesis in Geography and Environmental Education, Department of Science Education, University of Nigeria, Nsukka.

Patton, D. E., 2002. Framework for Ecological Risk. Assessment in Human Ecological Risk. USEPA. (United States Environmental Protection Agency's).

Sage, T., 2016. The impact of war on the degradation of ecology and environment. Addis Ababa: University Printing Press.

Saker, D., 2004. Researching audience. London: Arnold Publishers.

Scheufele, D. A., 1999. Framing as a theory of media effects. Journal of Communication, 749(1), 103-122. Doi.org/10.1111/j.1460-

2466.1999.tb02784.x

Shanahan, H., 2011. Strategic environmental analysis. Addis Ababa: SIDA: Department for Africa

Stables, A., 1996. Reading the environment as text. Literary theory and environmental education. Journal of Environmental Education Research, 2(2), 189195.Doi.org/10.1080/ 1350462960020205

Sullivan, R., 2007. Environmental problem and polices in Ethiopia: A survey in proceedings of a work shop on the
Development research. Addis Ababa:

University Printing Press.

Tankard, J. and Severin, C., 2000. An introduction to environmental education. Nairobi: Nairobi University Press.

Tengbers, G., 2015. Ethiopian research findings and conclusions. Addis Ababa: Ethiopia (unpublished source)

Tuchman, B. W., 1999. Conducting educational research $\left(5^{\text {th }}\right.$ Ed.) London: Harcourt Brace College Publishers.

Vandenberg, S. H., 2005. Global warning: Are we entering the green house centre? New York: Vintage Books.

Walle, H. E., Cornel, M. C. and Jong-vanden, Berg. L. T. W., 2002. Three years after the Dutch folic acid campaign: Growing socioeconomic differences. Preventive Medicine, 35, 65-69.

Wikipedia., 2009. Awareness. From Wikipedia, the free encyclopedia. Retrieved from www.wikipedia/search/engine/org.

World Health Organization., 2010. Environmental health. Retrieved from www.WHO/ environmental/health/pdf/org. 